\title{
Heterogeneity of Binding Sites for Glucocorticoid and the Glucocorticoid-Receptor Complex in Rat Livers
}

\author{
Makoto MURAMATSU, Makoto TANAKA, Atsuko FUJITA, \\ Susumu OTOMO and Hironaka AIHARA \\ Research Center. Taisho Pharmaceutical Co., Ltd., \\ Ohmiya, Saitama 330, Japan
}

Accepted June 8, 1984

\begin{abstract}
Glucocorticoid binding to cytoplasmic and nuclear fractions and glucocorticoid-receptor complex binding to the nuclear fraction were investigated using rat liver. The glucocorticoid-receptor complex binding to the nuclear fraction was temperature-dependent, saturable, small in amount and of high affinity. The affinity and number of the glucocorticoid-receptor complex binding to the nuclear fraction were altered according to the glucocorticoid. Both the $\mathrm{B}_{\max }$ of nuclear glucocorticoid-receptor complex binding and the affinity of glucocorticoid to the cytoplasmic fraction were correlated with the relative anti-inflammatory potencies of glucocorticoids reported by Hynes and Murad (1980) and Fried et al. (1958). These results suggest that the number of nuclear binding sites of the glucocorticoidreceptor complex depends on the ligand steroid which is bound to the receptor of the cytoplasmic fraction and may be involved in physiological and pharmacological potencies of the glucocorticoid in addition to the affinity of the glucocorticoid to the receptor.
\end{abstract}

Glucocorticoids, like other steroid hormones, are thought to act by controlling the rate of synthesis of protein (1). The glucocorticoids react with receptor proteins in the cytoplasm and form a steroid-receptor complex (2-4). The steroid-receptor complex undergoes an energy-dependent activation. enter the nucleus, and bind to acceptor sites, which are thought to trigger nuclearmediated events that result in the biological responses (1-4). Good correlations have been obtained between relative physiological and pharmacological potencies of the glucocorticoids and their affinities for the receptors of the cytoplasm in tissues in vitro and ex vivo (5). Non equivalence in glucocorticoidreceptor complex binding to nuclear acceptors was reported (6). Furthermore, a good correlation between the inhibition of nuclear glucocorticoid-receptor complex binding and loss of gene expression of casein in mammary glands in vitro was reported recently (7). In the present study, we have characterized the binding of glucocorticoid-receptor complexes and glucocorticoids to the nuclear fraction in addition to the glucocorticoids binding sites of the cytoplasmic fraction in rat liver and showed the heterogeneity of these binding sites.

\section{Materials and Methods}

Male albino rats of the Wistar strain weighing 150-200 g were used throughout the experiments.

Preparation of cytoplasmic fraction: After decapitation, the liver was perfused via the vena cava inferior with $20 \mathrm{ml}$ of ice-cold $0.9 \% \mathrm{NaCl}$. The liver was isolated and homogenized with 6 vol. of ice-cold $10 \mathrm{mM}$ Tris- $\mathrm{HCl}(\mathrm{pH} 7.5)$ buffer containing $1 \mathrm{mM}$ EDTA and $2 \mathrm{mM}$ dithiothreitol. Lipoproteinremoved supernatant was obtained by centrifugation of the homogenate at $100,000 \times \mathrm{g}$ for $60 \mathrm{~min}$ and lipid aspiration from the resultant supernatant, and it was used as the cytoplasmic fraction of rat liver.

Preparation of nuclear fraction: The nuclear fraction of rat liver was prepared according 
to the previously reported method (8), with slight modifications. The liver that was perfused with ice-cold $0.9 \% \mathrm{NaCl}$ was homogenized in $2 \mathrm{vol}$. of $0.32 \mathrm{M}$ sucrose containing $10 \mathrm{mM}$ Tris- $\mathrm{HCl}(\mathrm{pH} 7.5), 3 \mathrm{mM}$ $\mathrm{MgCl}_{2}$ and $1 \mathrm{mM}$ glutathione (buffer l) by a Teflon-glass homogenizer. The homogenate was filtered through two layers of siliconcoated gauze. The filtrate was centrifuged at $800 \times \mathrm{g}$ for $10 \mathrm{~min}$. After removal of the supernatant, the pellet was suspended with 4 vol. of buffer I and centrifuged again at $800 \times \mathrm{g}$ for $10 \mathrm{~min}$. Then, the resulting pellet was suspended with 3 vol. of buffer I, and $10 \mathrm{ml}$ of this suspension was layered on $18 \mathrm{ml}$ of $1.5 \mathrm{M}$ sucrose containing $10 \mathrm{mM}$ Tris $-\mathrm{HCl}$ $(\mathrm{pH} 7.5), 3 \mathrm{mM} \mathrm{MgCl}_{2}, 25 \mathrm{mM} \mathrm{KCl}$ and $1 \mathrm{mM}$ glutathione. Following centrifugation at $20,000 \times \mathrm{g}$ for $30 \mathrm{~min}$, the pellet was obtained and suspended with buffer I at the original wet weight volume. This suspension was used as the nuclear fraction of liver for nuclear acceptor and receptor assay.

Assay of glucocorticoid binding to cytoplasmic fraction: The binding was carried out as previously reported (9). Three hundred $\| l$ of cytoplasmic fraction was incubated with tritiated glucocorticoid at $0^{\circ} \mathrm{C}$ for $2 \mathrm{hr}$. The reaction was terminated by addition of $500 / \mathrm{ll}$ of activated charcoal solution ( $1 \%$ charcoal and $0.1 \%$ dextran (MW 60,000-90,000)/10 $\mathrm{mM}$ Tris $-\mathrm{HCl}(\mathrm{pH} 7.5))$ and was then mixed for $15 \mathrm{sec}$. The mixture was centrifuged at $3,000 \mathrm{rpm}$ for $10 \mathrm{~min}$ at $2^{\circ} \mathrm{C}$. From the supernatant, $0.2 \mathrm{ml}$ was transferred into a counting vial containing PCS-xylene $(1: 1)$ scintillation counting fluid. The radioactivity found in the presence of $10 / \mathrm{M}$ nonlabeled glucocorticoid was considered to be nonspecifically bound tritiated glucocorticoid and was subtracted from each experimental value found in the absence of the nonlabeled glucocorticoid (total binding) to obtain the amount of specifically bound tritiated glucocorticoid. As nonlabeled glucocorticoids, HC, DM and triamcinolone acetonide were used for the determination of specific binding of ${ }^{3} \mathrm{H}-\mathrm{HC},{ }^{3} \mathrm{H}-\mathrm{DM}$ and ${ }^{3} \mathrm{H}$-triamcinolone acetonide, respectively. Five $\mathrm{nM}$ tritiated glucocorticoids were used for the measurement of the affinities of steroids. Specific bindings of these tritiated glucocorticoids were found to be $90-95 \%$ of the total bindings. These specific binding values increased linearly with the protein concentration up to $3 \mathrm{mg}$ per assay and reached equilibrium within 100-120 min under these experimental conditions. The inhibition constants $\left(K_{i}\right)$ were determined by means of the equation proposed by Chen and Prusoff (10).

Assay of glucocorticoid binding to nuclear fraction: The binding activity of glucocorticoid to nuclear fraction was carried out by the exchange method of Anderson et al. (11). Five hundreds /ıl of nuclear fraction was incubated with tritiated glucocorticoid at 0 and $30^{\circ} \mathrm{C}$ for 90 min unless otherwise noted. Following standing for $10 \mathrm{~min}$ at $4{ }^{\circ} \mathrm{C}, 2 \mathrm{ml}$ of $10 \mathrm{mM}$ Tris- $\mathrm{HCl}$ (pH 7.5) containing $150 \mathrm{mM} \mathrm{NaCl}$ and $10 \%$ glycerol (buffer II) was added and mixed immediately. The mixture was centrifuged at $800 \times \mathrm{g}$ for $10 \mathrm{~min}$, and the supernatant was discarded. This procedure was repeated twice. The pellet was suspended with buffer II and filtered through a Milipore HAWP $(0.45 \mathrm{~km})$ filter under reduced pressure. The filter was placed in a counting vial containing PCSxylene scintillator. To obtain the specific binding of tritiated glucocorticoid, the radioactivity found in the presence of $10 / \mathrm{M}$ nonlabeled glucocorticoid was subtracted from the value of total binding as described above. The specific bindings of ${ }^{3} \mathrm{H}-\mathrm{HC}$ and ${ }^{3} \mathrm{H}-\mathrm{DM}$ to nuclear fraction were approximately 95 and $85 \%$, respectively, of the total binding at both 0 and $30^{\circ} \mathrm{C}$. These specific binding values increased linearly with the DNA concentration up to $160 \mu \mathrm{g}$ per assay.

Assay of glucocorticoid-receptor complex binding to nuclear fraction: Tritiated glucocorticoid-receptor complex was obtained by the incubation of $500 \mathrm{nM}{ }^{3} \mathrm{H}-\mathrm{HC},{ }^{3} \mathrm{H}-\mathrm{DM}$ and ${ }^{3} \mathrm{H}$-triamcinolone acetonide with the cytoplasmic fraction as described above. Then, $60-300 \mathrm{kl}$ of ${ }^{3} \mathrm{H}$-glucocorticoidreceptor complex were incubated with nuclear fraction (approximately $40 \% \mathrm{~g}$ DNA) for $60 \mathrm{~min}$ at 0 and $30^{\circ} \mathrm{C}$ in $500 / \mu l$ (final volume) unless otherwise noted. The specific binding of ${ }^{3} \mathrm{H}$-glucocorticoidreceptor complex was determined by subtracting the value of nonspecifically bound 
tritiated glucocorticoid-receptor complex. The nonspecific binding of the complex was determined by the incubation of the nuclear fraction with the complex obtained in the presence of $10 / \mathrm{M}$ nonlabeled glucocorticoid. The specific bindings of tritiated glucocorticoid-receptor complex were approximately 50 and $70 \%$ of the total binding of ${ }^{3} \mathrm{H}-\mathrm{HC}$ - and ${ }^{3} \mathrm{H}-\mathrm{DM}$-receptor complex. respectively, at $30^{\circ} \mathrm{C}$; and the specific binding of these complexes were 40 and $60 \%$, respectively, at $0^{\circ} \mathrm{C}$. For triamcinolone acetonide, specific binding was approximately $60 \%$ of the total binding both 0 and $30^{\circ} \mathrm{C}$. These specific binding values increased linearly with DNA concentration up to $80 \mu \mathrm{g}$ per assay.

Protein concentration was determined by the method of Lowry et al. (12) using bovine serum albumin as the standard. DNA concentration was assayed according to the method of Burton (13). The radioactivity was determined with a Packard model 3255 liquid scintillation spectrometer at a counting efficiency of $38-44 \%$. The dissociation constant $\left(K_{\mathrm{a}}\right)$ and maximum number of the binding sites $\left(B_{\max }\right)$ were determined by Scatchard analysis (14).

Drugs and materials: HC was obtained from Roussel UCLFA, and DM and triamcinolone acetonide were obtained from Sigma. 1, 2, 4- ${ }^{3} \mathrm{H}$-DM (S. A.: $46 \mathrm{Ci} / \mathrm{mmol}$ ) and $1,2,4(n)-{ }^{3} \mathrm{H}$-triamcinolone acetonide (S. A.: $22 \mathrm{Ci} / \mathrm{mmol}$ ) were obtained from RCC Amersham, and 1, $2{ }^{3} \mathrm{H}-\mathrm{HC}$ (S. A.:
$50.7 \mathrm{Ci} / \mathrm{mmol}$ ) was obtained from New England Nuclear. PCS scintillator was obtained from Amersham/Searle.

\section{Results}

${ }^{3} \mathrm{H}$-Glucocorticoid binding to the cytoplasmic fraction of rat livers: Scatchard plots of ${ }^{3} \mathrm{H}$-DM and ${ }^{3} \mathrm{H}$-triamcinolone acetonide bindings consisted of a single straight line (Fig. 1). The $B_{\max }$ and $K_{a}$ values of ${ }^{3} \mathrm{H}-\mathrm{DM}$ and ${ }^{3} \mathrm{H}$-triamcinolone acetonide were approximately equal. On the other hand, Scatchard analysis of ${ }^{3} \mathrm{H}-\mathrm{HC}$ binding revealed the presence of two different $\mathrm{HC}$ affinity binding sites (Fig. 1). The $B_{\max }$ and $K_{d}$ values of the high affinity binding site of ${ }^{3} \mathrm{H}-\mathrm{HC}$ was significantly smaller than those of ${ }^{3} \mathrm{H}$-DM and ${ }^{3} \mathrm{H}$-triamcinolone acetonide binding sites. The $K_{d}$ value of the low affinity binding site of ${ }^{3} \mathrm{H}-\mathrm{HC}$ was larger than those of ${ }^{3} \mathrm{H}-\mathrm{DM}$ and ${ }^{3} \mathrm{H}$-triamcinolone acetonide, while the $\mathrm{B}_{\max }$ of the ${ }^{3} \mathrm{H}-\mathrm{HC}$ binding site was approximately equal to the above two steroids.

Inhibition of specific ${ }^{3} \mathrm{H}$-glucocorticoid binding to the cytoplasmic fraction by $D M$, triamcinolone acetonide and $\mathrm{HC}$ : ${ }^{3} \mathrm{H}-\mathrm{DM}$ binding was completely inhibited by DM, triamcinolone acetonide and $\mathrm{HC}$ in a dosedependent manner (Fig. 2). Similarly, ${ }^{3} \mathrm{H}$ triamcinolone acetonide binding was inhibited by these glucocorticoids. In contrast, ${ }^{3} \mathrm{H}-\mathrm{HC}$ binding was not completely inhibited by DM and triamcinolone acetonide, except for HC (Fig. 2). Synthetic glucocorticoids,
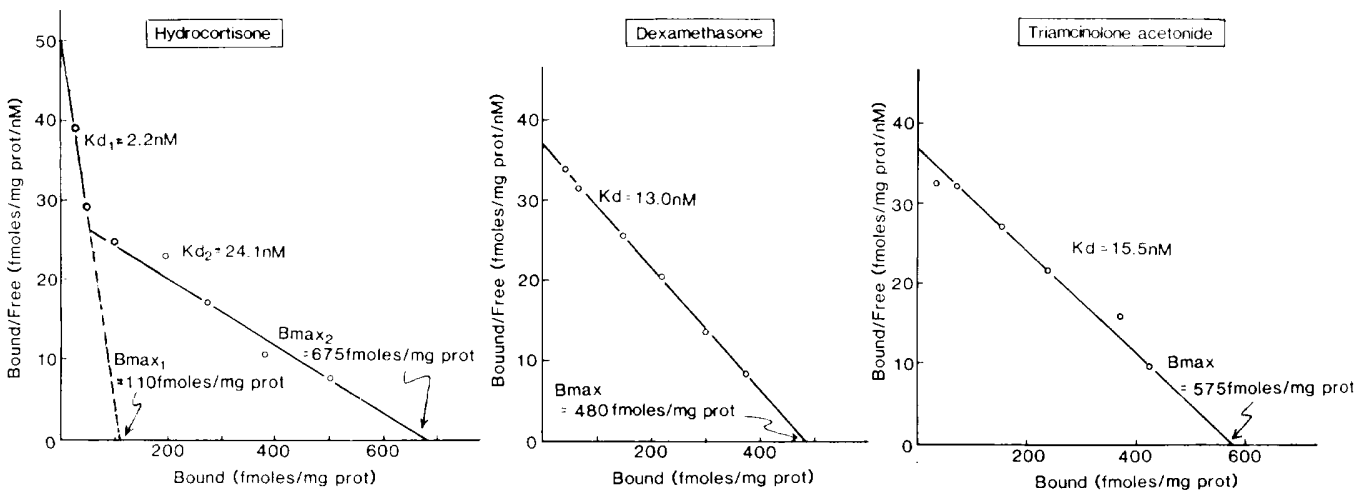

Fig. 1. Scatchard plot of ${ }^{3} \mathrm{H}-\mathrm{HC},{ }^{3} \mathrm{H}-\mathrm{DM}$ and ${ }^{3} \mathrm{H}$-triamcinolone acetonide binding to cytoplasmic fraction. Between 1 to $60 \mathrm{nM}$ tritiated glucocorticoids were used. Each point represents the mean obtained from 2 to 6 separate experiments performed in duplicate. 
DM and triamcinolone acetonide, did not inhibit the ${ }^{3} \mathrm{H}-\mathrm{HC}$ binding completely. These inhibitory effects reached a plateau at $100 \mathrm{nM}$ with $45 \%$ inhibition (Fig. 2).

${ }^{3} \mathrm{H}$-Glucocorticoid-receptor complex binding to the nuclear fraction: ${ }^{3} \mathrm{H}-\mathrm{DM}$ - and ${ }^{3} \mathrm{H}$ $\mathrm{HC}$-receptor complexes bound to the nuclear fraction time- and temperature- dependently (Fig. 3). Within $30 \mathrm{~min}$, the glucocorticoids-receptor complexes were saturated at both 0 and $30^{\circ} \mathrm{C}$. The amount of the ${ }^{3} \mathrm{H}$-DM-receptor complex binding was equal to that of the ${ }^{3} \mathrm{H}-\mathrm{HC}$-receptor complex at $0^{\circ} \mathrm{C}$. while at $30^{\circ} \mathrm{C}$, the binding of the ${ }^{3} \mathrm{H}$ DM complex was double the value of ${ }^{3} \mathrm{H}$ $\mathrm{HC}$ complex. The $\mathrm{B}_{\max }$ of ${ }^{3} \mathrm{H}-\mathrm{DM}$ - and ${ }^{3} \mathrm{H}-$
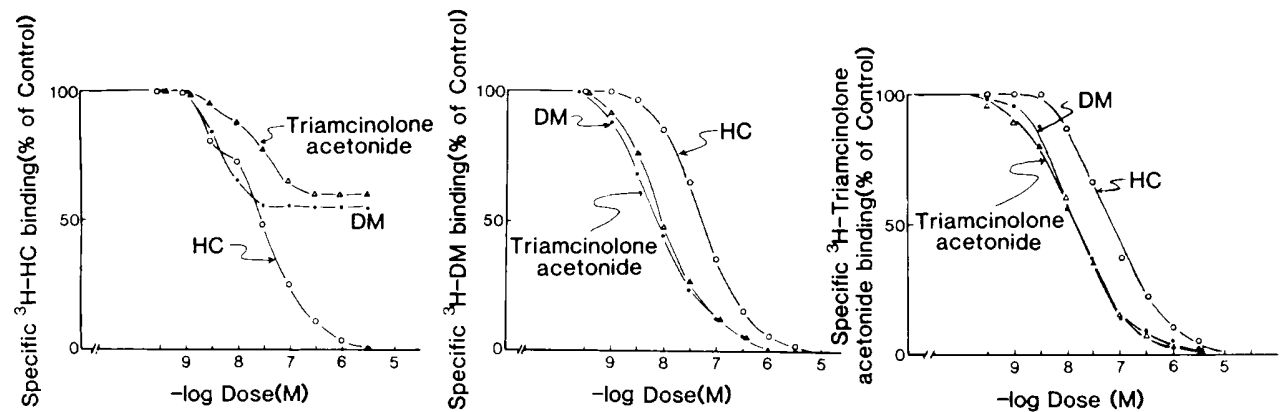

Fig. 2. Inhibition of specific ${ }^{3} \mathrm{H}-\mathrm{HC},{ }^{3} \mathrm{H}$-DM and ${ }^{3} \mathrm{H}$-triamcinolone acetonide binding to cytoplasmic fraction by various glucocorticoids. Each point represents the mean obtained from 3 to 5 separate experiments. Specific bindings of ${ }^{3} \mathrm{H}-\mathrm{HC},{ }^{3} \mathrm{H}$-DM and ${ }^{3} \mathrm{H}$-triamcinolone acetonide were $111.5 \pm 11.5$, $131.1 \pm 9.0$ and $147.0 \pm 8.5$ fmoles/mg prot., respectively, when $5 \mathrm{nM}$ tritiated glucocorticoids were used. $K_{i}$ values of $H C$, DM and triamcinolone acetonide were 49.3, 4.9 and $6.9 \mathrm{nM}$, respectively, for ${ }^{3} \mathrm{H}-\mathrm{DM}$ binding and 40,12 and $12 \mathrm{nM}$, respectively, for ${ }^{3} \mathrm{H}$-triamcinolone acetonide binding. $\mathrm{K}_{i}$ value of $\mathrm{HC}$ for ${ }^{3} \mathrm{H}-\mathrm{HC}$ was $27.5 \mathrm{nM}$. These values represent the mean of 3 to 5 separate experiments.

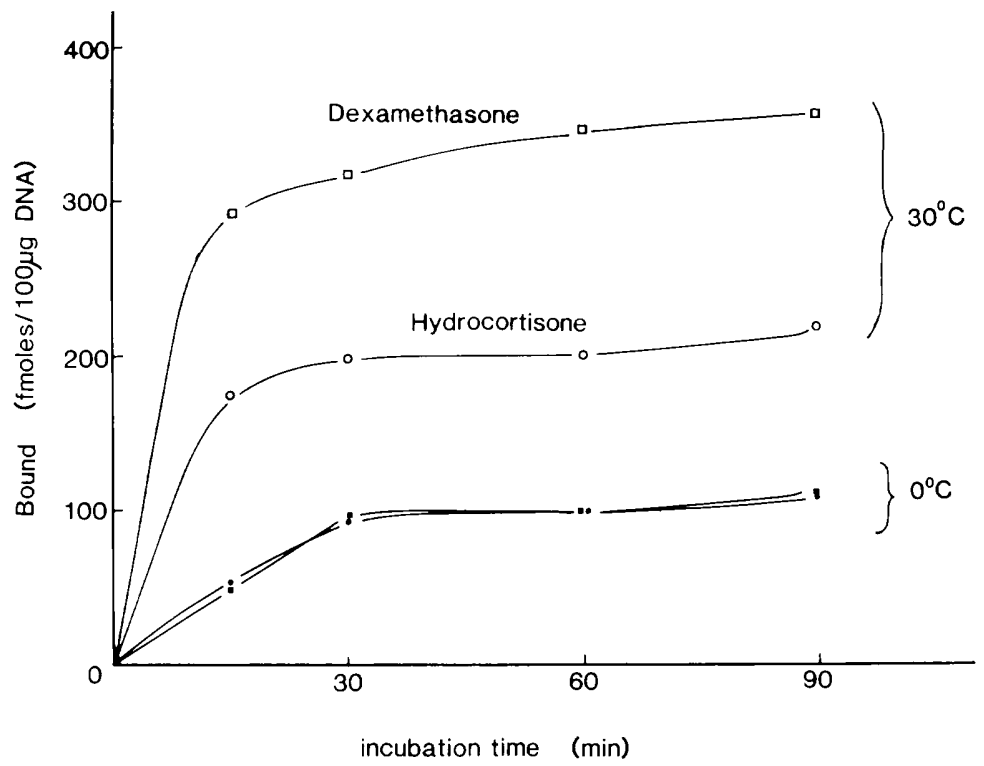

Fig. 3. Time and temperature dependency of ${ }^{3} \mathrm{H}-\mathrm{HC}$ - and ${ }^{3} \mathrm{H}-\mathrm{DM}$-receptor complex binding to nuclear fraction. As ligands, $1.81 \mathrm{nM}^{3} \mathrm{H}-\mathrm{HC}$-receptor complex and $1.37 \mathrm{nM}{ }^{3} \mathrm{H}$-DM-receptor complex were used. 
triamcinolone acetonide-receptor complexes were approximately equal but the value of the ${ }^{3} \mathrm{H}-\mathrm{HC}$-receptor complex was one-third of those for ${ }^{3} \mathrm{H}$-DM and ${ }^{3} \mathrm{H}$-triamcinolone, respectively (Fig. 4). Furthermore, the $K_{d}$ values of ${ }^{3} \mathrm{H}$-DM- and ${ }^{3} \mathrm{H}$-triamcinolone acetonide-receptor complexes were equal, but that of $\mathrm{HC}$ was about one-third those of
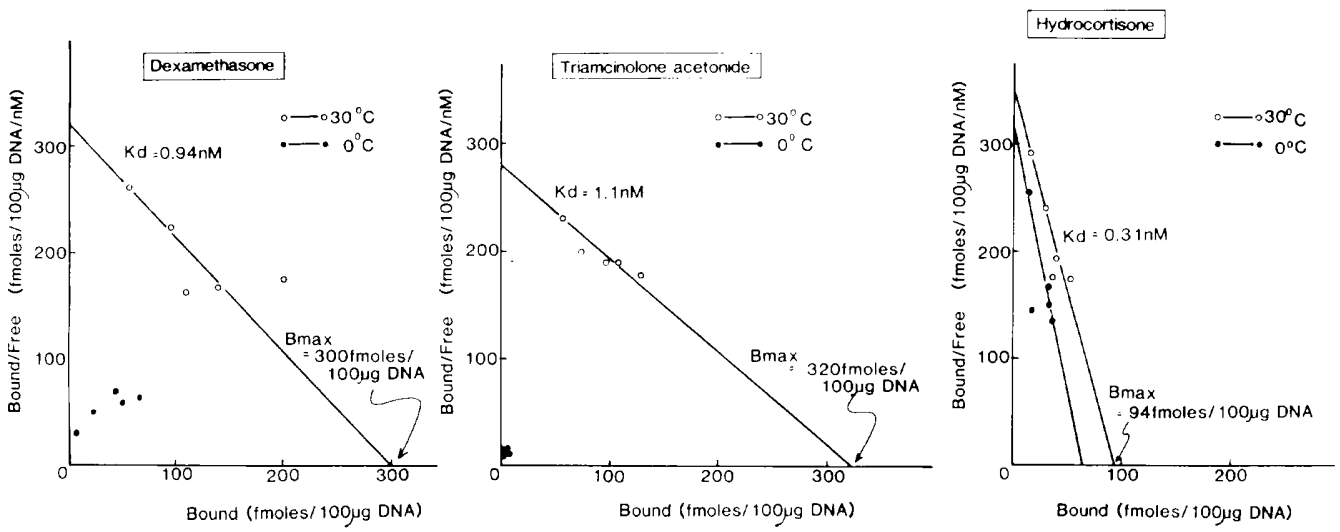

Fig. 4. Scatchard plot of ${ }^{3} \mathrm{H}-\mathrm{HC}$-, ${ }^{3} \mathrm{H}$-DM- and ${ }^{3} \mathrm{H}$-triamcinolone acetonide-receptor complex binding to nuclear fraction. An example of some experiments for each glucocorticoid was given. Each point represents the mean of triplicate experiments. $K_{d}$ and $B_{\max }$ values for ${ }^{3} \mathrm{H}-\mathrm{HC}$-receptor complex, ${ }^{3} \mathrm{H}-$ DM-receptor-complex and ${ }^{3} \mathrm{H}$-triamcinolone acetonide-receptor complex were $0.41 \mathrm{nM} \pm 0.10$, and $89.6 \mathrm{fmoles} / 100 \mu \mathrm{g} \mathrm{DNA} \pm 4.4,0.88 \mathrm{nM} \pm 0.06$ and $240 \mathrm{fmoles} / 100 \mu \mathrm{gDNA} \pm 30.5$, and $1.02 \mathrm{nM} \pm 0.2$ and $320 \mathrm{fmoles} / 100 \mu \mathrm{g} D N \pm 40$, respectively. These values represent the mean obtained from 3 separate experiments, perfomed in triplicate. $K_{d}$ and $B_{\max }$ values for ${ }^{3} \mathrm{H}-\mathrm{HC}$-receptor complex at $0^{\circ} \mathrm{C}$ were $0.21 \mathrm{nM}$ and $65 \mathrm{fmoles} / 100 \mu \mathrm{g}$ DNA, respectively. Between 0.07 to $1.5 \mathrm{nM}, 0.30$ to $1.67 \mathrm{nM}$ and 0.2 to $0.71 \mathrm{nM}$ were used as the concentrations for the glucocorticoid-receptor complex of ${ }^{3} \mathrm{H}-\mathrm{HC},{ }^{3} \mathrm{H}-\mathrm{DM}$ and ${ }^{3} \mathrm{H}$ triamcinolone acetonide, respectively.

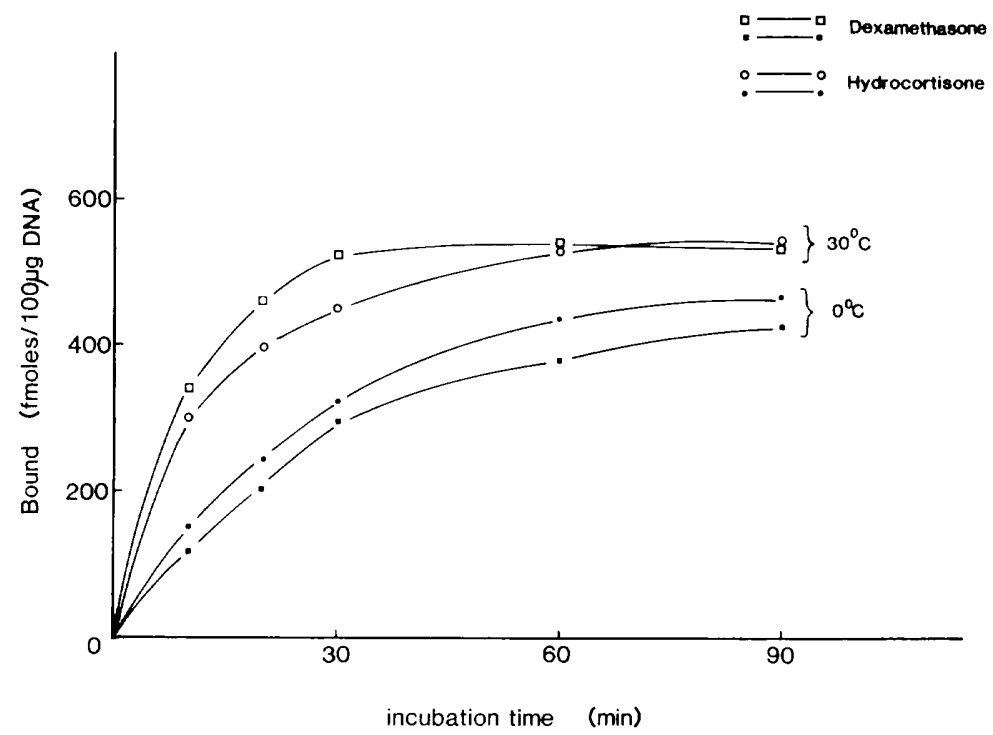

Fig. 5. Time and temperature dependency of ${ }^{3} \mathrm{H}-\mathrm{HC}$ and ${ }^{3} \mathrm{H}-\mathrm{DM}$ binding to nuclear fraction. Five $\mathrm{nM}$ tritiated glucocorticoids were used. 

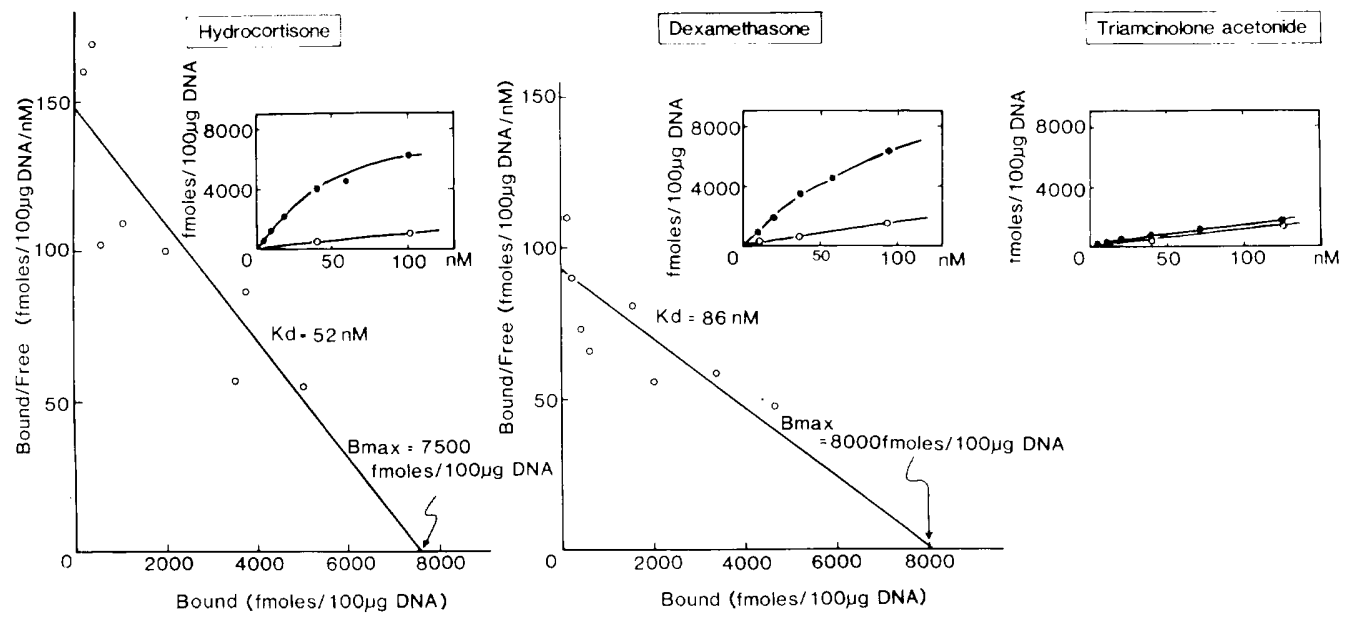

Fig. 6. Scatchard plot of ${ }^{3} \mathrm{H}-\mathrm{HC}$ and ${ }^{3} \mathrm{H}-\mathrm{DM}$ binding to nuclear fraction. Between 1 to $100 \mathrm{nM}$ tritiated glucocorticoids were used. Each point represents the mean obtained from 2 to 4 separate experiments performed in duplicate.

the above two synthetic glucocorticoids. ${ }^{3} \mathrm{H}$ Triamcinolone acetonide-receptor complex slightly bound to the nuclear fraction at $0^{\circ} \mathrm{C}$. The temperature dependency of the glucocorticoid-receptor complex binding to the nuclear fraction was most clearly observed with the triamcinolone acetonide-receptor complex (Fig. 4). There was no clear temperature dependence of ${ }^{3} \mathrm{H}-\mathrm{HC}$-receptor complex binding.

${ }^{3} \mathrm{H}$-Glucocorticoid binding to the nuclear fraction: ${ }^{3} \mathrm{H}$-Glucocorticoids binding to the nuclear fraction was also time- and temperature-dependent, while the temperature dependency was not as distinct as that for the glucocorticoid-receptor complex (Fig. 5). There was no difference in the amount of binding between $\mathrm{HC}$ and $\mathrm{DM}$ to the nuclear fraction. $\mathrm{DM}$ and $\mathrm{HC}$ bound to the nuclear fraction with a similar pattern at both 0 and $30^{\circ} \mathrm{C}$, respectively. The Scatchard analysis showed approximately equal values of $\mathrm{B}_{\max }$ for ${ }^{3} \mathrm{H}-\mathrm{HC}$ and ${ }^{3} \mathrm{H}-\mathrm{DM}$ (Fig. 6). These $\mathrm{B}_{\max }$ values were significantly larger than that of the glucocorticoid-receptor complex. On the other hand, the affinities of ${ }^{3} \mathrm{H}-\mathrm{HC}$ and ${ }^{3} \mathrm{H}$ DM were obviously lower than that of the glucocorticoid-receptor complex. The $K_{d}$ value of the latter one was about onehundredth of the former ones. In addition, the specific binding of ${ }^{3} \mathrm{H}$-triamcinolone acetonide to the nuclear fraction was different from those of ${ }^{3} \mathrm{H}-\mathrm{HC}$ and ${ }^{3} \mathrm{H}-\mathrm{DM}$ (Fig. 6).

\section{Discussion}

Numerous researchers have subdivided the binding sites of glucocorticoids by chromatographic analyses and suggested that the binding site of synthetic glucocorticoid is just one part of the sites which bind natural glucocorticoids (2, 15-18). Biological potencies of glucocorticoids have been explained by the affinity for the receptor, which is the only site that the synthetic glucocorticoids can bind (5). Certainly, in this study. HC bound to the DM binding site, but DM bound only to a part of the $\mathrm{HC}$ binding sites and the affinities of glucocorticoids for the ${ }^{3} \mathrm{H}-\mathrm{DM}$ and ${ }^{3} \mathrm{H}$-triamcinolone acetonide binding sites of the cytoplasmic fraction correlated approximately to their physiological and pharmacological potencies (1). On the other hand, there has been a great deal of controversy concerning the demonstration of nuclear acceptor sites. Several investigators have shown that the nuclear binding of the steroid-receptor complex is a saturable phenomenon and suggested the existence of a specific acceptor site $(3,19,20)$, while others claimed that a limited number of specific sites does not 
exist and that nuclear saturation is an artifact $(21-23)$. Much of this conflict probably stems from the difficulty in detecting a small number of specific sites in the presence of a large number of non specific sites (24). Buller et al. (19) succeeded in demonstrating the saturability, the high affinity of a small amount of sites and tissue specificity of the progesterone-receptor complex binding to nuclei in vitro by limiting the nonspecific binding. Furthermore, recent studies have shown that activation does occur in the cell and is not just an in vitro artifact $(25,26)$. In this study, we were able to observe the high affinity, saturable, small amount and temperature-dependent glucocorticoid-receptor complex binding by subtracting the nonspecific binding. It is wellknown that in mammals, one cell contains approximately $6 \mathrm{pg}$ of DNA (27), and we were able to observe 300 fmoles per 100 /g DNA as the maximum binding of the DM-receptor complex to the nuclear fraction. From these results, we were able to calculate that one liver cell contains $18 \times 10^{-23}$ moles of acceptor sites, that is 10,000 molecules of DM-receptor complexes bind to the acceptor per cell. This value was agreed with the binding of the progesterone-receptor complexes to the oviduct nuclei (19). Cidlowski and Munk (6) demonstrated the heterogeneity of nuclear glucocorticoid-receptor complex in the thymus cells. They incubated thymocytes and glucocorticoids, and they measured the distribution and kinetic behavior of the glucocorticoid-receptor complex in the intact cells, which was subjected to differential salt extraction and DNasel and DNasell digestion. As for glucocorticoid. they used HC, DM and triamcinolone acetonide and investigated the amount of the glucocorticoid-receptor complex binding to the nuclear fraction. The nuclear distribution of DM- and triamcinolone acetonidereceptor complexes were almost equal, but the $\mathrm{HC}$ complex was about half that of either synthetic compound in the salt-extractable and unextractable fraction. Moreover, they indicated that nuclear DM - and triamcinolone acetonide-receptor complexes are significantly more resistant to nuclease attack than the HC-receptor complex. Thus, they suggested that the natural and synthetic glucocorticoid form different types of nuclear complexes or associate with the nuclei in a different manner. However, in their study, the affinity and the maximum number of binding sites of the glucocorticoid-receptor complex are not clear. In this study, we investigated the complex binding to nuclei using kinetic analysis by incubating the isolated nuclei from rat liver and the glucocorticoid-receptor complex prepared previously by incubating the glucocorticoid with the cytoplasmic fraction of rat liver. We demonstrated that the values for the maximum number of binding sites for the DMand triamcinolone acetonide-receptor complexes were approximately equal, but that of the HC-receptor complex was one-third of the former ones. In addition, the number of temperature-dependent binding sites for the HC-receptor complex was about $10 \%$ of those for DM and triamcinolone acetonide. We have no direct evidence that the numbers of these high affinity, saturable, small amount and temperature-dependent bindings of glucocorticoid-receptor complex are responsible for the biological activity, but these numbers correlated with the biological potency of the glucocorticoids. Temperaturedependent, specific bindings of $\mathrm{HC}-$, DMand triamcinolone acetonide receptor complex were 24 (89 minus 65), 240 and 320 fmoles/ 100 /g DNA, respectively. Anti-inflammatory activity of DM is 25-170 times that of $\mathrm{HC}$ $(1,28)$, and triamcinolone acetonide has approximately the same anti-inflammatory effect as DM (29, 30). Moreover, Majumder et al. (7) indicated recently that there was a good correlation between the level of nuclear binding of the glucocorticoidreceptor complex and casein gene expression in the murine mammary gland in vitro. Putting all the data together, it may be considered that the nuclear binding of glucocorticoid-receptor complex plays an important role and the level of the binding is involved in the efficacy of the glucocorticoid. Free glucocorticoid bindings to the nuclear fraction were observed with a low affinity that was one-hundredth of that of the glucocorticoid-receptor complex, and there were no differences between $\mathrm{HC}$ and DM. 
In the case of triamcinolone acetonide, however, the specific binding to the nuclear fraction was not observed. So, it seems that the free glucocorticoid binding to the nuclear fraction does not have a significant role in the biological action of glucocorticoid. It has been considered that the affinity of glucocorticoid to the receptor protein in the cytoplasm is the most important factor which is related to the physioloical and pharmacological effect of the glucocorticoid (5).

The present study suggests that the number of the binding sites of glucocorticoidreceptor to nuclei may be involved in the efficacy of the glucocorticoid in addition to the affinity of the glucocorticoid to the receptor of the cytoplasm.

\section{References}

1 Hynes, R.C., Jr. and Murad, F.: Adrenocorticotropic hormone; adrenocortical steroids and their synthetic analogs; inhibitors of adrenocortical steroid biosynthesis. In The Pharmacological Basis of Therapeutics (6th edition), Edited by Gilman, A.G., Goodman, A. and Gilman, A., p. 1466-1497, MacMillan Publishing Co.. Inc., New York (1980)

2 Rousseau, G.G., Baxter, J.D. and Tomkins, G.M.: Glucocorticoid receptors: Relations between steroid binding and biological effects. J. Mol. Biol. 67, 99-115 (1972)

3 Higgins, S.T., Rousseau, G.G., Baxter, J.D. and Tomkins, G.M.: Early events in glucocorticoid action. J. Biol. Chem. 248, 5866-5872 (1973)

4 Yamamoto, K.R. and Alberts, B.: Specificity of the binding of the estrogen receptor protein to deoxyribonucleic acid. J. Biol. Chem. 249, 7076-7086 (1974)

5 Luzzani, F., Barone, D., Galliani, G. and Glasser, A.: Ex vivo binding to glucocorticoid receptor in the thymus of the adrenalectomized rat. Eur. J. Pharmacol. 87, 61-66 (1983)

6 Cidlowski, J.A. and Munk, A.: Heterogeneity of nuclear glucocorticoid receptor interaction. Adv. Exp. Med. Biol. 117, 71-93 (1979)

7 Majumder, P.K., Joshi, J.B. and Banerjee, M.R.: Correlation between nuclear glucocorticoid receptor levels and casein gene expression in murine mammary gland in vitro. J. Biol. Chem. 258, 6793-6798 (1983)

8 Sato, B., Nishizawa, Y., Noma, K., Matsumoto, $K$. and Yamamura, Y.: Estrogen-independent nuclear binding of receptor protein of rat uterine cytosol by removal of low molecular weight inhibitor. Endocrinology 104, 1474-1479 (1979)

9 Muramatsu, M., Tanaka, M., Otomo, S. and Aihara, H.: Characteristics of glucocorticoidbinding sites of rat liver.: Different effect of adrenalectomy on the binding. Japan. J. Pharmacol. 33, 955-963 (1983)

10 Chen, Y.C. and Prusoff, W.H.: Relationship between the inhibition constant $\left(\mathrm{K}_{\mathrm{i}}\right)$ and concentration of inhibitor which causes 50 percent inhibition (IC50) of an enzymatic reaction. Biochem. Pharmacol. 22, 3099-3108 (1973)

11 Anderson, J., Clark, J.H. and Peck, E.J., Jr.: Oestrogen and nuclear binding sites; determination of specific sites by $\left({ }^{3} \mathrm{H}\right)$ oestoradiol exchange. Biochem. J. 126, 561-567 (1972)

12 Lowry, O.H., Rosebrough, N.J., Farr, A.L. and Randall, R.J.: Protein measurement with the Folin phenol reagent. J. Biol. Chem. 193, 265275 (1951)

13 Burton, K.: The conditions and mechanism of the diphenylamine reaction for the colorimetric estimation of deoxyribonucleic acid. Biochem. J. 62, 315-327 (1956)

14 Scatchard, G.: The attractions of proteins for small molecules and ions. Ann. N.Y. Acad. Sci. 51, 660-672 (1949)

15 Beato, M. and Feigelson, P.: Glucocorticoidbinding proteins of rat liver cytosol. I. Separation and identification of the binding proteins. J. Biol. Chem. 247, 7890-7896 (1972)

16 Kobilnsky, M., Beato, M., Kalimi, M. and Feigelson, P.: Glucocorticoid-binding proteins of rat liver cytosol. II. Physical characterization and properties of the binding proteins. J. Biol. Chem. 247, 7897-7904 (1972)

17 Litwach, G. and Singer, S.: Liver cytosol corticosteroid binder II. A hormone receptor. J. Biol. Chem. 248, 7481-7486 (1973)

18 Agarwal, M.K.: Physicochemical comparison of the glucocorticoid-receptor from various tissues in the rat. Int. J. Biochem. 8, 7-10 (1977)

19 Buller, R.E., Scharder, W.T. and O'Malley, B.W.: Progesterone-binding components of chick oviduct. J. Biol. Chem. 250, 809-818 (1975)

20 Fang, S. and Liao, S.: Androgen receptors. Steroid and tissue-specific retention of a $17 \beta$ hydroxy- $5 \alpha$-androgen-3-one-protein complex by the cell nuclei of ventral prostate. J. Biol. Chem. 246, 16-24 (1971)

21 Chamnes, G.C., Jennings, A.W. and McGuire, W.L.: Oestrogen receptor is not restricted to target nuclei. Nature 241, 458-460 (1973)

22 Chamnes, G.C., Jennings, A.W. and McGuire, W.L.: Estrogen receptor binding to isolated nuclei. A nonsaturable process. Biochemistry 
13, 327-331 (1974)

23 Andre, J. and Rochefort, $\mathrm{H}$.: In vitro binding of the estroge receptor to DNA. Absence of saturation at equilibrium. FEBS lett. 50, 319-323 (1975)

24 Yamamoto, K.R. and Alberts, B.: Interaction of estradiol-receptor protein with the genome. Argument for the existence of undetected specific site. Cell 4, 301-310 (1975)

25 Munck, A. and Forey, R.: Activation of steroid hormone-receptor complexes in intact target cells in physiological conditions. Nature 278, $752-754$ (1979)

26 Markovic, R.D. and Litwack, G.: Activation of liver and kidney glucocorticoid-receptor complexes occurs in vitro. Arch. Biochem. Biophys. 202, 374-379 (1980)

27 Lehninger, A.L.: DNA and the structure of the genetic materials. In Biochemistry. The Molecular Basis of Cell Structure and Function (2nd edition), p. 859-890. Worth Publishers, Inc., New York (1975)

28 Arth, G.E., Fried, J., Johnston, D.B.R., Hoff, D.R., Saett, L.H., Silber, R.H., Stoerk, H.C. and Winter, C.A.: 16-Methylated steroids, II. $16 \alpha$ methyl analogs of cortisone, a new groups of anti-inflammatory steroids, $9 \alpha$ halo derivatives. J. Am. Chem. Soc. 80, 3161-3163 (1958)

29 Fried. J., Borman, A., Kessler, W.B., Grabowich, P. and Sabo, E.F.: Cyclic 16 $\alpha, 17 \alpha$-ketals and acetals of $9 \alpha$-fluoro-16 $\alpha$-hydroxy-cortisol and -prednisolone. J. Am. Chem. Soc. 80, 23382339 (1958)

30 Miki, T.: Steroids hormone. In Drug Design, Edited by Yamabe. S., p. 249-288, Asakura Shoten. Tokyo (1979) (in Japanese) 